and for the very numerous, generally excellent and sometimes unique illustrations, especially those showing nineteenth-century buildings and other structures. Painstakingly compiled by experts, they will form a valuable addition to the library of any engineer or architect who is no mere technician treating concrete as just a medium of construction "here and now", but who is alive to the fascination of the long evolution which had its origins in a remote past and which still continues. A reader equipped with this positive mental attitude will find it an infinitely absorbing book of many facets, to which he will turn again and again with pleasure and interest.

C.V.A.

\title{
Handbuch der Fertigteil-Bauweise
}

(Manual of prefabricated construction)

mit grossformatigen Stahl- und Spannbetonelementen: Konstruktion, Berechnung und Bauausführung

Dr-Ing. Tikamér Konz

Band 1: Grundlagen Dach- und Deckenelemente Wadntafeln

pp. xii, 298 DM 68

Band 1I: Hallen- und Flachbauten Zweckbauten

pp. xii, 427 DM 88

Band III: Mehrgeschossbauten der Industrie und Verwaltang

Schut und UniversitatsbäutenWohnbauten

pp. xii, 359 DM 75

Three bound volumes $\left(11 \frac{1}{1} \times 8 \frac{1}{2}\right.$ in. $)$ published by Bauverlag GmbH, Wiesbaden, Berlin. Second edition. Vol. I: 1966. Vols II and III: 1967.

These three impressive volumes totalling nearly 1,100 pages and containing some 2,000 illustrations (photographs, line drawings, diagrams), together with numerous tables of data, form an almost encyclopaedic work of reference and instruction on 'heavy' prefabricated construction with large precast concrete (reinforced or prestressed) components of all kinds.

The first volume is concerned with principles and fundamentals (methods of manufacture, techniques, handling, erection and so on) and deals more particularly with roof, floor and wall units. Shed-type (single-storey) industrial buildings and special-purpose structures (such as grand-stands, cooling towers, silos) are treated in the second volume. The third is devoted to multi-storey construction comprising industrial, administrative, educational and residential buildings.

A large number of details of joints, structural connexions, layouts and so on are presented in the well executed line drawings, which were, for the most part, prepared in the author's own drawing office. The photographs show many and varied examples of actual structures, completed or in course of erection, in both Western and Eastern European countries, the United States and others.
In this book the author has endeavoured to deal comprehensively and systematically with his vast subject in its many interrelated aspects (technical, architectural, economic, functional), making use of an impressive array of published information-hundreds of references are given-and the fruits of his own experience and development work as a designer and consultant in his own right.

It is, of course, not possible from a general inspection, however careful, to arrive at a complete and conclusive opinion on the merits of a publication of this scope. The true test of its worth will consist in the service it can render to the practising designer over a period of time. There can, however, be no doubt but that this important set of volumes is entitled to a special place on the bookshelf of every structural engineering design office. It is essentially a book to 'live with', to be consulted frequently and thoroughly in dealing with practical problems of design.

Though written in German, it can justifiably be regarded as an 'international' publication in the sense that it presents a wealth of information, suggestions and ideas which will be of considerable value to designers all over the world.

C.V.A. 